\title{
Dividend Payout Ratio Pada Sektor Trade \& Services di Indonesia Stock Exchange (BEI)
}

\author{
Lidia Jane Heryes \\ Universitas Esa Unggul \\ e-mail: lidiajane.heryes@gmail.com
}

\begin{tabular}{ccc}
\hline Diterima & Direvisi & Disetujui \\
$21-05-2021$ & $21-07-2021$ & $14-09-2021$ \\
\hline
\end{tabular}

\begin{abstract}
Abstrak - Rasio pembayaran dividen merupakan hal yang menjadi pusat perhatian investor di pasar modal. Secara umum, setiap investor mengharapkan rasio pembayaran dividen yang rutin dan stabil. Tujuan penelitian ini untuk mengkaji apakah rasio lancar, rasio hutang, return on asset, dan pertumbuhan aset mempengaruhi suatu sektor trade dan services dalam membayarkan rasio pembayaran dividen kepada investor. Untuk mencapai tujuan ini menggunakan laporan keuangan tahunan yang diperoleh dari Bursa Efek Indonesia (BEI) pada sektor trade dan services. Subjek penelitian merupakan 10 perusahaan yang rutin memberikan dividen dari tahun 2014 sampai tahun 2017. Data yang terkumpul dianalisis menggunakan STATA versi 16.0 dan model regresi data panel yang terpilih yaitu Random Effect (RE). Hasil pengujian menunjukkan bahwa rasio lancar, rasio hutang, return on asset, dan pertumbuhan aset sebesar 54,75\% secara serentak mempengaruhi rasio pembayaran dividen (DPR). Secara parsial rasio lancar tidak mempengaruhi rasio pembayaran dividen, rasio hutang mempengaruhi secara negatif terhadap rasio pembayaran dividen, ROA mempengaruhi secara positif terhadap DPR, dan pertumbuhan aset tidak mempengaruhi rasio pembayaran dividen pada sektor trade dan services.
\end{abstract}

Kata Kunci: rasio pembayaran dividen, pasar modal, sektor trade dan services

Abstract - The dividend payout ratio is the center of attention of investors in the capital market. In general, every investor expects a routine and stable dividend payout ratio. The purpose of this study is to examine whether current ratios, debt ratios, return on assets, and asset growth affect a trade and services sector in paying dividend payout ratios to investors. To achieve this goal using annual financial reports obtained from the Indonesia Stock Exchange (IDX) in the trade and services sector. The research subjects were 10 companies that routinely paid dividends from 2014 to 2017. The data collected were analyzed using STATA version 16.0 and the selected panel data regression model is Random Effect (RE). The test results show that the current ratio, debt ratio, return on assets, and asset growth of $54.75 \%$ simultaneously affect the dividend payout ratio (DPR). Partially the current ratio does not affect the dividend payout ratio, the debt ratio negatively affects the dividend payout ratio, ROA positively affects the DPR, and asset growth does not affect the dividend payout ratio in the trade and services sector.

Keywords: dividend payout ratio, capital market, trade and services sector

\section{PENDAHULUAN}

Di era pasar bebas atau globalisasi, perusahaan berjuang untuk menghadapi persaingan ekonomi yang semakin ketat. Dalam persaingan ketat, persoalan yang sering dihadapi oleh perusahaan adalah masalah pendanaan. Pasar modal menjadi alternatif solusi dalam masalah pendanaan. Penelitian (Usman et al., 1997) mendefinisikan pasar modal sebagai instrumen keuangan jangka panjang dalam bentuk modal sendiri dan hutang. Investor yang menginvestasikan uangnya di pasar modal bertujuan untuk mendapatkan pendapatan atau pengembalian dari investasi tersebut, baik dalam capital gain atau dividend. Menurut (Lintner, 1956) mengungkapkan bahwa investor lebih menyukai berinvestasi di perusahaan yang memberikan dividend daripada capital gain, karena dividend lebih dapat diprediksi daripada capital gain, dimana harga saham ditentukan oleh kekuatan pasar.

Secara umum, setiap investor mengharapkan rasio pembayaran dividen yang rutin dan stabil. Teori pensinyalan dividen yang dirumuskan oleh (Miller dan Modigliant, 1961) berpendapat bahwa pengumuman tentang pembayaran dividen memberikan sinyal tentang kesehatan keuangan perusahaan. Pembayaran dividen yang meningkat dibandingkan dengan pembayaran tahun sebelumnya adalah indikator bahwa perusahaan memiliki nilai yang menunjang di masa depan. Sebaliknya, pengurangan dividen adalah indikator yang buruk, karena ini menunjukkan kurangnya likuiditas perusahaan untuk mempertahankan tingkat pembayaran dividen di masa depan (Utami \& Tatang Ary Gumanti, 2019). 
Menurut (Utami dan Tatang Ary Gumanti, 2019); (Abor dan Amidu, 2006) menyatakan bahwa variabel-variabel yang mempengaruhi keputusan perubahan pembayaran dividen suatu perusahaan seperti rasio lancar (current ratio), pertumbuhan aset (asset growth), rasio leverage (debt to equity) dan laba atas ekuitas (ROE). Variabel lain yang dapat mempengaruhi kebijakan dividen adalah ukuran perusahaan dan risiko keuangan. Ukuran perusahaan dapat menjadi proksi dari siklus hidup perusahaan begitu juga posisi leverage keuangan. Leverage keuangan menunjukkan proporsi penggunaan pinjaman atau hutang sebagai sumber pembiayaan. Semakin tinggi hutang, semakin tinggi juga beban bunga yang dapat menurunkan laba bersih, yang akhirnya mempengaruhi kebijakan dividen. Perusahaan dengan tingkat likuiditas rendah cenderung menahan laba untuk memenuhi hutang jangka pendek sehingga perusahaan memutuskan untuk tidak membayar dividen tinggi (Abor \& Amidu, 2006). Begitu juga perusahaan dengan pertumbuhan aset tinggi cenderung mempertahankan labanya untuk mendanai investasi sehingga dividen yang dibayarkan akan lebih rendah (Manneh \& Naser, 2015). Dapat disimpulkan bahwa pertumbuhan aset perusahaan mempengaruhi secara negatif dengan kebijakan dividen.

Beberapa penelitian terdahulu yang dilakukan oleh (Utami dan Tatang Ary Gumanti, 2019) dengan variabel penelitian yang digunakan yaitu rasio lancar (current ratio), rasio hutang (debt ratio), pertumbuhan aset (asset growth), laba berdasarkan aset (return on asset), dan ukuran perusahaan terhadap dividend payout ratio (DPR) pada perusahaan yang terdaftar di BEI pada tahun 20112015 menunjukan bahwa kemampuan untuk mendapatkan laba berdasarkan aset dan pertumbuhan perusahaan dianggap sebagai faktor yang mempengaruhi pembayaran dividen atau dapat dikatakan variabel return on asset dan asset growth mempengaruhi secara positif terhadap dividend payout ratio. Selanjutnya (Sumail, 2018) melakukan penelitian menggunakan variabel debt ratio, EBIT, managerial ownership, institutional ownership, size terhadap dividend payout ratio dengan subjek perusahaan non finansial yang terdaftar di BEI pada tahun 2013-2016 menunjukan bahwa ukuran perusahaan, EBIT, institutional ownership dianggap sebagai faktor yang mempengaruhi pembayaran dividen. Kemudian penelitian (Abor dan Amidu, 2006) dalam menentukan faktor-faktor yang mempengaruhi dividend payout ratios in Ghana menunjukan bahwa variabel-variabel yang mempengaruhi rasio pembayaran dividen yaitu profitabilitas, arus kas dan pajak.

Manajemen perusahaan memiliki peran utama dalam pengambilan keputusan terkait dengan rasio pembayaran dividen. Setiap perusahaan memiliki kriteria dan karakter mengenai pembagian dividen.
Perbedaan rasio pembayaran dividen dari satu ke perusahaan yang lain menyebabkan rasio pembayaran dividen menjadi topik yang menarik untuk diteliti. Berdasarkan penelitian terdahulu dimana variabelvariabel yang mempengaruhi rasio pembayaran dividen tidak selalu konsisten, maka di penelitian ini mencoba untuk mengkaji kembali pengaruh variabel rasio lancar, rasio hutang, return on asset, dan pertumbuhan aset terhadap rasio pembayaran dividen dengan subjek penelitiannya yaitu perusahaan yang rutin memberikan dividen dari tahun 2014 sampai tahun 2017, data sampel yang diambil berdasarkan data laporan keuangan tahunan.

Adapun tujuan penelitian ini yaitu untuk mengkaji apakah variabel rasio lancar, rasio hutang, return on asset dan pertumbuhan aset mempengaruhi suatu perusahaan trade dan services dalam membayarkan rasio pembayaran dividen kepada investor.

\section{Landasan Teori}

\section{a. Rasio Pembayaran Dividen}

Menurut (Dybvig dan Zender, 2016) rasio pembayaran dividen menggambarkan pengembalian investasi (menghasilkan keuntungan) untuk pemegang saham/investor. Dividen dapat didistribusikan dalam bentuk pembayaran tunai (cash dividend), saham atau aset perusahaan. Variabel rasio pembayaran dividen adalah persentase dividen per lembar saham dibagi dengan laba bersih per saham. Secara umum, pembagian dividen pada tahun tertentu berdasarkan pada pembagian dividen tahun lalu (Utami \& Tatang Ary Gumanti, 2019).

\section{b. Rasio Lancar}

Menurut (Brigham dan Houston, 2009) rasio lancar mencerminkan penggunaan aset-aset lancar untuk memenuhi kewajiban/hutang lancar. Perusahaan dengan rasio lancar yang kecil berkecenderungan untuk membayar dividen dalam rasio kecil juga, karena kas perusahaan tersebut disimpan untuk memenuhi kebutuhan dana yang mendesak, seperti membayar hutang perusahaan ketika jatuh tempo (Utami \& Tatang Ary Gumanti, 2019). Semakin perusahaan dapat memenuhi hutang jangka pendeknya maka perusahaan tersebut semakin efektif dalam menggunakan aset lancarnya serta semakin besar juga kemampuan untuk membayar dividen (Rahayu \& Hari, 2016).

Penelitian terdahulu oleh (Jasim Al-Ajmi dan Hussain, 2016); (Labhane dan Jitendra Mahakud, 2016); dan (Herawati dan Fauzia, 2018) menemukan bahwa rasio lancar mempengaruhi secara positif dan signifikan terhadap rasio pembayaran dividen. Hal ini juga sejalan dengan penelitian (Utami dan Tatang Ary Gumanti, 2019) menyatakan bahwa rasio lancar merupakan pertimbangan utama ketika perusahaan memutuskan untuk membayar atau tidaknya suatu dividen. Maka pernyataan hipotesis: 
H1: Rasio lancar mempengaruhi secara positif terhadap rasio pembayaran dividen.

\section{c. Rasio Hutang}

Rasio hutang mencerminkan kemampuan perusahaan untuk melunasi semua kewajiban menggunakan aset. Perusahaan dengan leverage yang tinggi berarti perusahaan tersebut memiliki pembayaran tetap yang besar untuk pembiayaan eksternal, yang mungkin digunakan untuk pembayaran dividen. Leverage tinggi meningkatkan biaya transaksi dan risiko perusahaan. Rasio hutang biasanya digunakan untuk pengukuran likuiditas jangka panjang. Dari sudut pandang investor, rasio hutang yang lebih rendah, semakin aman posisi perusahaan tersebut (Purwanto \& Elen, 2017).

Semakin tinggi rasio hutang perusahaan, semakin besar juga laba yang harus digunakan untuk melunasi hutang maka hal ini akan mengurangi jumlah dividen yang dibayarkan (Gumanti, 2013). Penelitian (Ravid dan Sarig, 2016) menunjukkan hubungan yang kuat antara tingkat hutang dan kebijakan dividen yang menunjukkan bahwa tingkat hutang menentukan tingkat dividen suatu perusahaan. Penelitian sebelumnya yang dilakukan oleh (Manneh dan Naser, 2015); (Jabbouri, 2016); (Labhane dan Jitendra Mahakud, 2016); (Purwanto dan Elen, 2017); (Utami dan Tatang Ary Gumanti, 2019); dan (Patra et al., 2012) menyatakan bahwa rasio hutang mempengaruhi secara negatif dan signifikan terhadap DPR. Peningkatan rasio hutang akan menurunkan DPR, dan penurunan rasio hutang akan meningkatkan DPR. Maka pernyataan hipotesis:

H2: Rasio hutang mempengaruhi secara negatif terhadap rasio pembayaran dividen.

\section{d. Return on Asset (ROA)}

Indikator untuk menilai profitabilitas perusahaan. Profitabilitas mengacu pada return on asset (ROA). Rasio yang mencerminkan kontribusi aset untuk menghasilkan laba bersih. Rasio ini mengukur tingkat keuntungan yang diperoleh dari penjualan dan investasi dalam efektivitas manajemen. Semakin baik ROA, semakin baik pula kemampuan suatu perusahaan untuk menghasilkan laba. Dapat dikatakan aset dijadikan sebagai modal dan tolak ukur pengembalian berupa laba (Jordan, 2003).

Pembayaran dividen menggunakan laba perusahaan, sehingga fluktuasi laba tahunan yang diperoleh mempengaruhi rasio pembayaran dividen. Maka semakin meningkatnya laba maka kemungkinan terjadi peningkatan rasio pembayaran dividen (Manneh \& Naser, 2015). Penelitian (Lintner, 1956) menunjukkan bahwa perusahaan dengan laba tinggi cenderung mempertahankan labanya untuk investasi di masa depan, terutama ketika perusahaan berencana untuk memperluas bisnis. Sementara itu, perusahaanperusahaan yang berada di puncak kedewasaan tidak memiliki alternatif investasi lain selain membayar dividen dari laba. Perusahaan yang memiliki laba stabil cenderung membayar dividen dengan persentase tetap untuk mempertahankan citra perusahaan.

Penelitian sebelumnya yang dilakukan oleh (Jabbouri, 2016); (Labhane dan Jitendra Mahakud, 2016); dan (Utami dan Tatang Ary Gumanti, 2019) menunjukan bahwa variabel yang mempengaruhi rasio pembayaran dividen yaitu kemampuan untuk mendapatkan laba berdasarkan aset (ROA) atau dapat dikatakan variabel return on asset mempengaruhi secara positif terhadap rasio pembayaran dividen. Maka pernyataan hipotesis:

H3: ROA mempengaruhi secara positif terhadap rasio pembayaran dividen.

\section{e. Pertumbuhan Aset}

Faktor pertumbuhan suatu aset perusahaan diwakili oleh pertumbuhan penjualan tahunan, laba atas kekayaan bersih dan pertumbuhan pendapatan per saham (Kania \& Bacon, 2005). Selain itu, (Albright \& Wingram, 2007) menyatakan bahwa pemegang saham menyadari nilai pertumbuhan. Banyak perusahaan yang sedang berkembang, seperti Microsoft dan Intel tidak membayar dividen atau hanya membayar dividen rendah. Namun, perusahaan tersebut menghasilkan jutaan untuk investor karena nilai saham yang lebih tinggi. Perusahaan tersebut lebih suka mempertahankan penghasilannya untuk menciptakan produksi yang lebih besar, kapasitas penjualan yang lebih tinggi, dan mendapatkan banyak keuntungan (Albright \& Wingram, 2007).

Sehingga dapat dikatakan perusahaan dengan tingkat pertumbuhan rendah biasanya mempunyai tingkat laba ditahan yang lebih tinggi daripada pembayaran dividen (Utami \& Tatang Ary Gumanti, 2019). Penelitian (Miller dan Modigliant, 1961) menunjukkan secara teoritis bahwa tingkat dividen ditentukan oleh tingkat pertumbuhan aset. Semakin tinggi pertumbuhan perusahaan maka terdapat aktivitas ekspansi bisnis yang berpeluang peningkatan keuntungan, sehingga meningkatkan citra perusahaan yang dapat meningkatkan harga saham dan meningkatkan rasio pembayaran dividen.

Penelitian sebelumnya yang dilakukan oleh (Utami dan Tatang Ary Gumanti, 2019); (Jabbouri, 2016); (Labhane dan Jitendra Mahakud, 2016); (Purwanto dan Elen, 2017); dan (Patra et al., 2012) melaporkan hubungan negatif antara pertumbuhan aset dan rasio pembayaran dividen. Maka semakin tinggi pertumbuhan aset, semakin kecil rasio pembayaran dividennya. Maka pernyataan hipotesis:

H4: Pertumbuhan aset mempengaruhi secara negatif terhadap rasio pembayaran dividen. 
Berdasarkan pengembangan hipotesis tersebut, berikut kerangka pemikiran penelitian ini:

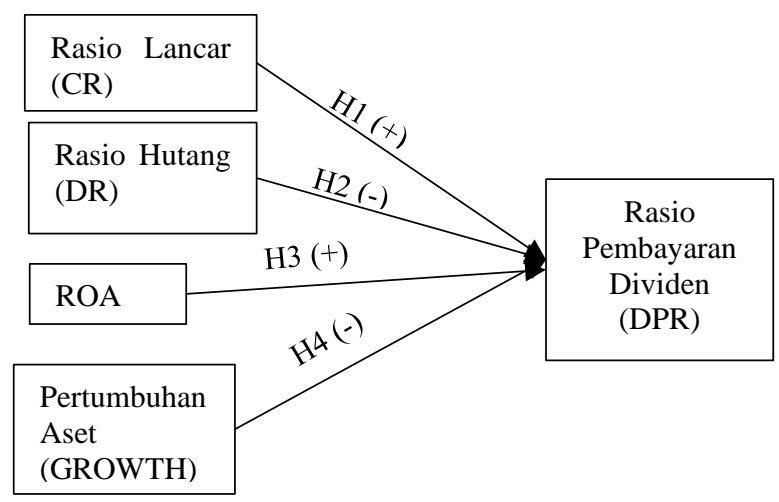

Sumber: Data Diolah (2021)

Gambar 1. Kerangka Pemikiran Penelitian

\section{METODE PENELITIAN}

Desain yang dilakukan dalam penelitian ini adalah pendekatan secara kuantitatif. Teknik pengambilan data untuk penelitian ini secara purposive sampling berdasarkan data sekunder yang diperoleh dari Bursa Efek Indonesia (BEI) pada sektor industri trade dan services. Sebanyak 10 perusahaan diambil sebagai sampel dimana perusahaan tersebut merupakan perusahaan yang rutin memberikan dividen selama periode 2014-2017.

Tabel 1. Daftar Sampel Perusahaan BEI Sektor Trading dan Services

\begin{tabular}{|c|c|l|}
\hline No & Kode Emiten & \multicolumn{1}{|c|}{ Nama Perusahaan } \\
\hline 1 & AKRA & AKR Corporindo Tbk \\
\hline 2 & AMRT & Sumber Alfaria Trijaya Tbk \\
\hline 3 & ASGR & Astra Graphia Tbk \\
\hline 4 & ATIC & Anabatic Technologies Tbk \\
\hline 5 & CSAP & Catur Sentosa Adiprana Tbk \\
\hline 6 & LPPF & $\begin{array}{l}\text { Matahari Department Store } \\
\text { Tbk }\end{array}$ \\
\hline 7 & MLPT & Multipolar Technology Tbk \\
\hline 8 & ACES & Ace Hardware Indonesia Tbk \\
\hline 9 & FAST & Fast Food Indonesia Tbk \\
\hline 10 & ERAA & Erajaya Swasembada Tbk \\
\hline
\end{tabular}

Sumber: Data Diolah (2021)

Variabel yang digunakan yaitu rasio pembayaran dividen (DPR) sebagai variabel dependen, dan rasio lancar (CR), rasio hutang (DR), return on asset (ROA), dan pertumbuhan aset (GROWTH) sebagai variabel independen.

Tabel 2. Definisi Operasional Variabel Penelitian

\begin{tabular}{|c|c|c|c|c|}
\hline $\begin{array}{c}\text { Nama } \\
\text { Variabel }\end{array}$ & $\begin{array}{c}\text { Jenis } \\
\text { Variabel }\end{array}$ & Definisi Operasional Variabel & Indikator & Satuan \\
\hline DPR & Dependent & $\begin{array}{l}\text { Persentase dividen per lembar } \\
\text { saham dibagi dengan laba bersih }\end{array}$ & $=\frac{\text { Dividend per share }}{E P S(\text { Laba bersih per saham dasar })}$ & $\%$ \\
\hline $\mathrm{CR}$ & Independent & $\begin{array}{l}\text { Rasio aset lancar dengan hutang } \\
\text { lancar }\end{array}$ & $=\frac{\text { Current asset }}{\text { Current liabilities }}$ & $\mathrm{x}$ \\
\hline DR & Independent & Rasio total liabilities dengan total & $\begin{array}{l}\text { Total liabilities } \\
\text { Total }\end{array}$ & $\mathrm{x}$ \\
\hline ROA & Independent & Rasio yang menunjukkan seberapa & $\begin{array}{l}\text { Total assets } \\
\text { Earning (profit after tax) }\end{array}$ & $\%$ \\
\hline GROWTH & Independent & $\begin{array}{l}\text { banyak aset berkontribusi untuk } \\
\text { menciptakan laba bersih } \\
\text { Nilai yang menunjukan } \\
\text { pertumbuhan perusahan }\end{array}$ & $\begin{array}{c}\text { Total assets } \\
=\frac{(\text { Total aset tahun } t-\text { total aset tahun } t-1)}{\text { Total aset tahun } t-1}\end{array}$ & $\%$ \\
\hline
\end{tabular}

Sumber: Data Diolah (2021)
Pengujian dilakukan dengan bantuan software Stata versi 16.0. Pengujian hipotesis menggunakan uji regresi data panel. Pengujian dimulai dengan tahapan penentuan model Pooled Least Square (PLS), Fixed Effect (FE) dan Random Effect (RE); dilanjut dengan pengujian normalitas, multikolineritas, heteroskedastisitas, dan autokorelasi; diakhiri dengan pengujian hipotesis (uji signifikansi serentak, uji signifikansi parsial, uji goodness of fit).

\section{HASIL DAN PEMBAHASAN}

Untuk menentukan model regresi diantara PLS, FE dan RE maka dilakukan uji Chow dan uji Hausman.

\section{Uji Chow}

Berfungsi untuk menentukan pilihan antara model PLS dan FE dengan melihat output FE. Dalam uji Chow ini terdapat hipotesis yaitu: H0: PLS; H1: FE. Jika Prob $>\mathrm{F}<0,05$ maka H1 diterima, berlaku sebaliknya. Berdasarkan output data STATA 16.0, nilai Prob $>$ F output FE yaitu 0,0077, sehingga dapat dinyatakan $\mathrm{H} 1$ diterima (pilihan terbaik adalah FE).

\section{Uji Hausman}

Berfungsi untuk memastikan pilihan antara model FE dan RE. Dalam uji Hausman ini terdapat hipotesis yaitu H0: RE; H1: FE. Jika Prob >Chi $2<0,05$ maka H1 diterima, berlaku sebaliknya. Berdasarkan output STATA 16.0 diperoleh nilai Prob>Chi2 yaitu 0,0562, sehingga dapat dinyatakan $\mathrm{H} 1$ ditolak (pilihan terbaik adalah RE).

Berikut tabel ringkasan hasil uji estimasi model:

Tabel 3. Hasil Uji Estimasi Model

\begin{tabular}{|l|l|l|}
\hline $\begin{array}{l}\text { Uji Penentuan } \\
\text { Model }\end{array}$ & \multicolumn{1}{|c|}{ Hasil } & \multicolumn{1}{|c|}{ Kesimpulan } \\
\hline $\begin{array}{l}\text { Uji Chow (PLS } \\
\text { vs FE) }\end{array}$ & $\begin{array}{l}\text { Prob }>\text { F }= \\
0,0077\end{array}$ & Terima H1 = FE \\
\hline $\begin{array}{l}\text { Uji Hausman } \\
\text { (FE vs RE) }\end{array}$ & $\begin{array}{l}\text { Prob Chi2 }= \\
0,0562\end{array}$ & Tolak H1 = RE \\
\hline
\end{tabular}

Sumber: Data diolah dari Ouput STATA 16.0 (2021)

Berdasarkan informasi di tabel 3 telah dibuktikan dari hasil pengujian estimasi model terbaik menunjukan bahwa model Random Effect (RE) adalah model yang terbaik untuk dapat digunakan sebagai model untuk pengujian selanjutnya yaitu pengujian hipotesis. Namun sebelum pengujian hipotesis, model RE tersebut dilakukan pengujian normalitas, multikolineritas, heteroskedastisitas, dan autokorelasi.

\section{Uji Normalitas}

Uji Normalitas untuk menguji apakah residual berdistribusi normal atau tidak. Pada penelitian ini menggunakan metode uji Shapiro Wilk STATA. Jika nilai $\operatorname{Prob}>\mathrm{z}>0,05$ maka residual berdistribusi normal. Berdasarkan output STATA 16.0 diperoleh 
nilai Prob $>\mathrm{z}$ yaitu 0,37992, sehingga dapat dinyatakan residual berdistribusi normal.

Tabel 4. Hasil Uji Normalitas

\begin{tabular}{r|rcccc}
\multicolumn{7}{c}{ Shapiro-Wilk w test for normal data } \\
Variable & Obs & W & V & z & Prob $>z$ \\
\hline res & 40 & 0.97075 & 1.156 & 0.306 & 0.37992
\end{tabular}

Sumber: Ouput STATA 16.0 (2021)

\section{Uji Multikolineritas}

Model regresi yang baik harus bebas dari multikolineritas. Jika nilai VIF $<10$, maka model regresi bebas dari multikolineritas. Berdasarkan output STATA 16.0 diperoleh nilai VIF yaitu 2,20, sehingga dapat dinyatakan model regresi bebas dari multikolineritas.

Tabel 5. Hasil Uji Multikolineritas

\begin{tabular}{r|rr} 
Variable & VIF & $1 /$ VIF \\
\hline CR & 3.32 & 0.301475 \\
DR & 3.31 & 0.301949 \\
GROWTH & 1.09 & 0.915646 \\
ROA & 1.06 & 0.943918 \\
\hline Mean VIF & 2.20 &
\end{tabular}

Sumber: Ouput STATA 16.0 (2021)

\section{Uji Heteroskedastisitas}

Pada penelitian ini menggunakan metode uji Breusch Pagan. Jika nilai Prob>chi2 > 0,05 maka model regresi bebas dari heteroskedastisitas. Berdasarkan output STATA 16.0 diperoleh nilai Prob>chi2 yaitu 0,2785 , sehingga dapat dinyatakan bahwa model regresi bebas dari heteroskedastisitas.

Tabel 6. Hasil Uji Heterokedastisitas

Breusch-Pagan / Cook-Weisberg test for heteroskedasticity Ho: Constant variance

Variables: fitted values of DPR

$\operatorname{chi2}(1)=1.17$

Prob $>$ chi2 $=0.2785$

Sumber: Ouput STATA 16.0 (2021)

\section{Uji Autokorelasi}

Pada uji autokorelasi data cross section tidak diwajibkan, namun berdasarkan pengujian crosssectional time-series FGLS regression menggunakan STATA 16.0 didapatkan hasil "no autocorrelation", sehingga dapat dinyatakan bahwa model regresi tidak terdapat masalah autokorelasi.

Tabel 7. Hasil Uji Autokorelasi

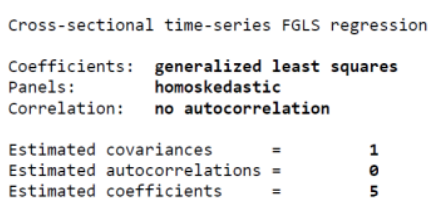

Log likelihood $\quad=-155.1291$

Sumber: Ouput STATA 16.0 (2021)

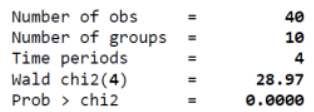

Maka setelah dibuktikan bahwa data yang tersedia terdistribusi normal, model RE yang terpilih bebas dari multikolinearitas, heteroskedastisitas dan tidak terjadi masalah autokolerasi. Sehingga dapat langsung dilakukan pengujian hipotesis. Pengujian hipotesis dilakukan dengan uji signifikansi serentak, uji signifikansi parsial, goodness of fit test berdasarkan hasil regresi data panel. Berikut hasil regresi data panel:

\begin{tabular}{|c|c|c|c|c|c|c|c|}
\hline \multicolumn{4}{|c|}{$\begin{array}{l}\text { Random-effects GLS regression } \\
\text { Group variable: Perusahaan }\end{array}$} & \multicolumn{4}{|c|}{ Number of obs $=$} \\
\hline \multicolumn{4}{|c|}{ R-sq: } & \multicolumn{4}{|c|}{ Obs per group: } \\
\hline \multirow{2}{*}{\multicolumn{4}{|c|}{$\begin{aligned} \text { within } & =0.1970 \\
\text { between } & =0.5475\end{aligned}$}} & & \multicolumn{3}{|c|}{ min $=$} \\
\hline $\begin{array}{l}\text { between } \\
\text { overall }\end{array}$ & & & & & & $\begin{array}{l}\text { avg }= \\
\operatorname{ax}= \\
\operatorname{ar}\end{array}$ & $\begin{array}{r}4.0 \\
4\end{array}$ \\
\hline \multirow[b]{2}{*}{$\operatorname{corr}\left(u_{-} i, x\right)$} & \multirow{2}{*}{\multicolumn{3}{|c|}{$=\theta$ (assumed) }} & \multirow{2}{*}{\multicolumn{3}{|c|}{ Wald chi2(4) }} & \multirow{2}{*}{$\begin{array}{r}14.03 \\
0.0072\end{array}$} \\
\hline & & & & & & $=$ & \\
\hline DPR & coef. & Std. Err. & $z$ & $P>|z|$ & {$[95 \%$} & conf. & Interval] \\
\hline$C R$ & -5.678342 & 2.938319 & -1.93 & 0.053 & -11.4 & 3734 & .0806566 \\
\hline DR & -73.09318 & 24.23957 & -3.02 & 0.003 & -120. & 5019 & -25.5845 \\
\hline ROA & .6140267 & .2780363 & 2.21 & 0.027 & .069 & 854 & 1.158968 \\
\hline GROWTH & .01401073 & .1766511 & 0.01 & 0.995 & -.345 & 1567 & .3473027 \\
\hline _cons & 80.06445 & 18.03401 & 4.44 & 0.000 & 44.7 & 1843 & 115.4105 \\
\hline sigma_u & 8.1631185 & & & & & & \\
\hline sigma_e & 9.8795907 & fraction & f varian & cedue t t & 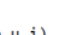 & & \\
\hline & $.465 / 1945$ & & & & & & \\
\hline Ouput ST & ATA 16.0 & (2021) & & & & & \\
\hline
\end{tabular}

\section{Uji Signifikansi Serentak}

Uji untuk melihat apakah variabel rasio lancar (CR), rasio hutang (DB), return on asset (ROA), dan pertumbuhan aset (GROWTH) secara serentak mempengaruhi variabel rasio pembayaran dividen (DPR) dengan menggunakan data prob $>$ chi2. Jika nilai dari prob $>$ chi $2<\alpha(0,05)$ maka $\mathrm{H} 0$ ditolak. Berdasarkan gambar 2 diperoleh nilai prob>chi2 yaitu 0,0072 , maka $\mathrm{H} 0$ ditolak atau dapat dinyatakan variabel rasio lancar (CR), rasio hutang (DB), return on asset (ROA), dan pertumbuhan aset (GROWTH) secara serentak mempengaruhi variabel rasio pembayaran dividen (DPR).

\section{Uji Signifikansi Parsial}

Uji untuk melihat apakah variabel rasio lancar (CR), rasio hutang (DB), return on asset (ROA), dan pertumbuhan aset (GROWTH) secara parsial mempengaruhi variabel rasio pembayaran dividen (DPR) dengan menggunakan data $\mathrm{P}>|\mathrm{z}|$. Jika nilai dari $\mathrm{P}>|\mathrm{z}|<\alpha(0,05)$ maka $\mathrm{H} 0$ ditolak. Berdasarkan gambar 2 berikut masing-masing hasil dari variabel: a. nilai $\mathrm{P}>|\mathrm{z}|$ variabel $\mathrm{CR}=0,053$ maka $\mathrm{H} 0$ diterima (rasio lancar tidak mempengaruhi rasio pembayaran dividen).

b. nilai $\mathrm{P}>|\mathrm{z}|$ variabel $\mathrm{DR}=0,003$ maka $\mathrm{H0}$ ditolak (rasio hutang mempengaruhi secara negatif terhadap rasio pembayaran dividen).

c. nilai $\mathrm{P}>|\mathrm{z}|$ variabel $\mathrm{ROA}=0,027$ maka $\mathrm{H} 0$ ditolak (return on asset mempengaruhi secara positif terhadap rasio pembayaran dividen).

d. nilai $\mathrm{P}>|\mathrm{z}|$ variabel GROWTH $=0,995$ maka H0 diterima (pertumbuhan aset tidak mempengaruhi rasio pembayaran dividen). 


\section{Goodness of Fit Test}

Uji untuk menjelaskan seberapa besar variabel rasio lancar (CR), rasio hutang (DB), return on asset (ROA), dan pertumbuhan aset (GROWTH) mempengaruhi variabel rasio pembayaran dividen (DPR) dengan menggunakan data R-sq. Berdasarkan gambar 2 nilai R-sq yaitu 0.5475 , dapat dinyatakan bahwa sebesar $54,75 \%$ variabel rasio lancar (CR), rasio hutang (DB), return on asset (ROA), dan pertumbuhan aset (GROWTH) mempengaruhi variabel rasio pembayaran dividen (DPR). Sisanya kemungkinan dipengaruhi oleh variabel lain.

\section{Persamaan Regresi}

Berikut didapatkan persamaan regresi sebagai berikut:

\section{DPR $=$ 80,06445 - 5,678342CR - 73,09318 DR + 0,6140267 ROA + 0,001073 GROWTH}

Rasio lancar tidak mempengaruhi rasio pembayaran dividen pada sektor trade dan services. Hal ini berbeda dengan hasil empiris penelitian (Jasim AlAjmi dan Hussain, 2016); (Labhane dan Jitendra Mahakud, 2016); (Herawati dan Fauzia, 2018); dan (Utami dan Tatang Ary Gumanti, 2019) yang telah membuktikan bahwa rasio lancar mempengaruhi secara positif dan signifikan terhadap rasio pembayaran dividen. Hal ini karena perusahaan pada sektor ini sebagian besar penjualannya dilakukan secara tunai sehingga mampu mengakomodir kewajibannya dan rasio ini tidak menjadi hal utama dalam pembayaran dividen. Hasil penelitian sejalan dengan penelitian (Muhammadinah \& Alfan Jamil, 2015) yang menunjukan hasil bahwa rasio lancar tidak mempengaruhi rasio pembayaran dividen.

Rasio hutang mempengaruhi secara negatif terhadap rasio pembayaran dividen. Hasil empiris yang sama dengan hasil penelitian yang dilakukan oleh (Manneh dan Naser, 2015); (Jabbouri, 2016); (Labhane dan Jitendra Mahakud, 2016); (Purwanto dan Elen, 2017); (Utami dan Tatang Ary Gumanti, 2019); dan (Patra et al., 2012) menyatakan bahwa rasio hutang mempengaruhi secara negatif dan signifikan terhadap rasio pembayaran dividen. Semakin tinggi rasio hutang perusahaan, maka semakin besar juga laba yang harus digunakan untuk melunasi hutang sehingga akan mengurangi rasio pembayaran dividen (Gumanti, 2013).

ROA mempengaruhi secara positif terhadap DPR. Hasil empiris yang sejalan dengan penelitian (Jabbouri, 2016); (Labhane dan Jitendra Mahakud, 2016); dan (Utami dan Tatang Ary Gumanti, 2019) menunjukan bahwa kemampuan untuk mendapatkan laba berdasarkan aset dianggap sebagai salah satu variabel yang mempengaruhi rasio pembayaran dividen (DPR) atau dapat dikatakan variabel ROA mempengaruhi secara positif signifikan terhadap DPR. Menurut (Manneh dan Naser, 2015) perusahaan akan meningkatkan pembayaran dividen seiring dengan meningkatnya laba.

Pertumbuhan aset tidak mempengaruhi rasio pembayaran dividen pada sektor trade dan services. Hasil empiris berbeda dengan hasil penelitian (Utami dan Tatang Ary Gumanti, 2019); (Jabbouri, 2016); (Labhane dan Jitendra Mahakud, 2016); (Purwanto dan Elen, 2017); dan (Patra et al., 2012) menyatakan bahwa pertumbuhan aset mempengaruhi secara negatif terhadap rasio pembayaran dividen. Hasil empiris yang sama dengan penelitian (Mauris \& Nora, 2019) yang telah menunjukan hasil pertumbuhan aset tidak mempengaruhi rasio pembayaran dividen.

\section{KESIMPULAN}

Data penelitian yang berasal dari 10 perusahaan trade dan services yang tertera di BEI pada tahun 20142017, diperoleh hasil yang menunjukan bahwa rasio lancar, rasio hutang, return on asset, dan pertumbuhan aset sebesar $54,75 \%$ secara serentak mempengaruhi rasio pembayaran dividen (DPR). Secara parsial rasio lancar tidak mempengaruhi rasio pembayaran dividen, rasio hutang mempengaruhi secara negatif terhadap rasio pembayaran dividen, ROA mempengaruhi secara positif terhadap DPR, dan pertumbuhan aset tidak mempengaruhi rasio pembayaran dividen pada sektor trade dan services.

Bagi perusahaan trade dan services dalam meningkatkan laba setiap tahunnya dapat melakukan efektifitas penggunaan aktiva perusahaan, efisiensi biaya operasional dan pemanfaatan hutang yang tepat. Peningkatan keuntungan/laba berpeluang meningkatkan citra perusahaan yang dapat meningkatkan harga saham sehingga diharapkan dapat meningkatkan antusias para pemegang saham untuk menginvestasikan dananya. Dengan demikian perusahaan trade dan services dapat membantu dalam peningkatan pertumbuhan ekonomi Indonesia.

Bagi calon pemegang saham yang ingin berinvestasi dapat mempertimbangkan rasio lancar, ukuran perusahaan dan rasio hutang dalam membantu mengambil keputusan berinvestasi pada suatu perusahaan.

Pada penelitian selanjutnya diharapkan dapat mengkolaborasikan dengan variabel lain seperti financial leverage ratio, taxes, harga saham serta mencoba melakukan proyeksi nilai penting lainnya pada sektor industri lain yang terdaftar di BEI.

\section{REFERENSI}

Abor, J. Y., \& Amidu, M. (2006). Determinants of dividend payout ratios in Ghana. The Journal of Risk Finance, 7, 136-145. 
https://doi.org/10.1108/15265940610648580

Albright, T. ., \& Wingram, R. (2007). Financial Accounting. International Student Edition.

Brigham, E. F., \& Houston, J. F. (2009). FUNDAMENTALS OF FINANCIAL Twelfth Edition. South Western Cengage Learning.

Dybvig, P. H., \& Zender, J. F. (2016). Capital Structure and Dividend Irrelevance with Asymmetric Information. 4(1), 201-219.

Gumanti, T. A. (2013). Kebijakan Dividen Teori, Empiris dan Implikasi (1st ed.). UPP STIM YKPN.

Herawati, A., \& Fauzia, F. I. (2018). The Effect of Current Ratio, Debt to Equity Ratio and Return on Asset on Dividend Payout Ratio in Subsector Automotive and Component Listed in Indonesia Stock Exchange in Period 2012 2016.2018 , 1076-1086. https://doi.org/10.18502/kss.v3i10.3450

Jabbouri, I. (2016). Determinants of corporate dividend policy in emerging markets : Evidence from MENA stock markets. Research in International Business and Finance, 37, 283298.

https://doi.org/10.1016/j.ribaf.2016.01.018

Jasim Al-Ajmi, \& Hussain, H. A. (2016). Corporate dividends decisions: evidence from Saudi Arabia. The Journal of Risk Finance, 12(1), 4156.

https://doi.org/10.1108/15265941111100067

Jordan, R. W. (2003). Fundamentals of Corporate Finance. McGraw-Hill Primis.

Kania, S. L., \& Bacon, F. W. (2005). WHAT FACTORS MOTIVATE THE CORPORATE DIVIDEND DECISION ? ASBBS E-Journal, 1 .

Labhane, N. B., \& Jitendra Mahakud. (2016). Determinants of Dividend Policy of Indian Companies. 36-55.

Lintner, J. (1956). Distribution of Incomes of Corporations Among Dividens, Retained Earnings, and Taxes. 46(2), 97-113.

Manneh, M. A., \& Naser, K. (2015). Determinants of Corporate Dividends Policy : Evidence from an Emerging Economy. International Journal of Economics and Finance, 7(7), 229-239. https://doi.org/10.5539/ijef.v7n7p229

Mauris, F. I., \& Nora, A. R. (2019). The Effect of Collaterallizable Assets, Growth in Net Assets , Liquidity, Leverage and Profitability on Dividend Policy. Budapest International Research and Critics Institute (BIRCIJournal), 937-950. doi: https://doi.org/10.33258/birci.v4i1.1695
Miller, M. H., \& Modigliant, F. (1961). The University of Chicago Press. The Journal of Business, 34(4), 411-433.

Muhammadinah, \& Alfan Jamil, M. (2015). PENGARUH CURRENT RATIO, DEBT TO EQUITY RATIO, TOTAL ASSET TURNOVER DAN RETURN ON ASSET TERHADAP DIVIDEN PAYOUT RATIO PADA PERUSAHAAN SEKTOR INDUSTRI BARANG KONSUMSI YANG TERDAFTAR DI BURSA EFEK INDONESIA. I-Economics Journal, 1(1), 69-92.

Patra, T., Poshakwale, S., \& Ow-yong, K. (2012). Determinants of corporate dividend policy in Greece. Applied Financial Economics, 10791087.

https://doi.org/10.1080/09603107.2011.63973 4

Purwanto, \& Elen, M. (2017). Determinants of Dividend Payout Ratio in Property Companies : Evidence from Indonesia. International Journal of Economic Perspectives, 11(3), 346358.

Rahayu, A. S., \& Hari, M. (2016). Pengaruh Current Ratio dan Quick Ratio terhadap Kebijakan Dividen Melalui Return On Equity Pada Perusahaan Manufaktur yang Terdaftar di BEI Tahun 2014. Jurnal Ekonomi Bisnis.

Ravid, S. A., \& Sarig, O. H. (2016). Financial Signalling by Committing to Cash Outflows. 26(2), 165-180.

Sumail, L. O. (2018). Corporate governance and dividend payout ratio in non-financial firms listed in Indonesian Stock Exchange. Business and Economic Horizons Volume, 14(4), 851861.

Usman, M., Riphat, M. A. S., \& Ika, S. (1997). Pengetahuan Dasar Pasar Modal. Institut Bankir Indonesia.

Utami, E. S., \& Tatang Ary Gumanti. (2019). Analysis of cash dividend policy in Indonesia stock exchange. Investment Management and Financial Innovations, 16(3), 93-105. https://doi.org/10.21511/imfi.16(3).2019.10 